\title{
Internationalization and Diversification Strategies of Agricultural Cooperatives: a Quantitative Study of the Agricultural Cooperatives in the State of Parana
}

\author{
Claudia Monica Ritossa * \\ E-mail address: ritossa@gmail.com \\ Universidade Federal do Paraná \\ Curitiba, PR, Brazil.

\section{Sergio Bulgacov} \\ E-mail address: s.bulgacov@ufpr.br \\ Universidade Federal do Paraná \\ Curitiba, PR, Brazil.
}

\begin{abstract}
This study investigates the impact of internationalization on the results achieved by agricultural cooperatives in the State of Parana, at the same time examining strategies for diversification of markets as well as diversification of products aimed exclusively at international markets. Of the 28 cooperatives to be included in the study, $67.9 \%$ returned valid structured questionnaires. The collected data was submitted to non-parametric statistical analysis. Key findings suggest the following: external markets are served by indirect and direct exports; product diversification strategies are motivated by the creation of revenue alternatives to members and by the reduction of risks associated to agricultural business; diversification strategies are conceived to develop new business in accordance with market demand and to expand customized products from the existing portfolio; the formation of strategic alliances prioritizes access to distribution channels abroad; internationalization and diversification strategies produce positive results both from an economic and a social perspective.
\end{abstract}

Key words: internationalization strategy; diversification strategy; agricultural cooperatives.

Received 13 July 2008; received in revised form 26 February 2009.

Copyright (C) 2009 Brazilian Administration Review. All rights reserved, including rights for translation. Parts of this work may be quoted without prior knowledge on the condition that the source is identified.

* Corresponding author: Claudia Monica Ritossa

Universidade Federal do Paraná, Setor de Ciências Sociais Aplicadas, Departamento de Administração Geral e Aplicada, Rua Prefeito Lothário Meissner, 632, Jardim Botânico, Curitiba, PR, 80210-170, Brazil. 


\section{INTRODUCTION}

This study aims to observe internationalization strategies while taking into account not only alternatives for diversification of markets but also for diversification of products aimed exclusively at international markets and the effects of both on the results achieved by agricultural cooperatives in the state of Parana. In addition to the complexity involved in the formulation of internationalization strategies, this field of study also has some specific details that somehow affect the whole research process. In different countries, agricultural cooperatives have gradually become more consistent and diversified due to the adoption of advanced management structures. The simple export of commodities that has traditionally linked the cooperatives to the global market is giving way to the development of added value agro-industrialization practices. The diversification of agricultural activities is considered a possibility to increase the surplus of cooperatives; it is a powerful and competitive alternative for entry to new markets that provide a chance to operate at a higher level of commercialization of products abroad and overcome protectionist barriers. Studies about world market tendencies stress the decline of raw material and commodity exports, which have been overtaken by processed and industrialized products (Lopes, 2003).

In Parana, a state in the southern part of Brazil that is traditionally known for its rural activities, 53\% of the agricultural economy belongs to agricultural cooperatives, which accounts for $18 \%$ of the Gross Domestic Product [GDP] (Organization of Cooperatives of the State of Parana [OCEPAR], 2006). This segment, according to the Organization of Cooperatives of the State of Parana (OCEPAR, 2007), exported, in 2006, the equivalent of $\$ 852,900,000$, accounting for $30.1 \%$ of total exports from Brazilian cooperatives and $8.5 \%$ of the total exports of the State. These results put the agricultural cooperatives of Parana in the second place in the ranking of Brazilian exports (Ministério do Desenvolvimento, Indústria e Comércio Exterior, Secretaria de Comércio Exterior [MDIC/SECEX], 2007) and confirm the tendency to look farther afield. Strategic investments have been made in segments of agribusiness, either for implanting, expanding or modernizing agro-industries. According to Ferreira and Denardin (2006), six hundred million reais have already been invested in 2005 and seven hundred and ninety five million in 2006. By 2010, a further three and a half billion reais will be injected into the system. These data indicate that cooperatives have been considering product diversification to meet external market demands while internationalizing. Due to the complexity and implications inherent to the strategic decision to internationalize, the intention of this exploratory and descriptive study is to contribute to the increasing knowledge of the subject and provide a basis for further study. Therefore, there are two reasons that favor the investigation of the internationalization process of agricultural cooperatives: the scarcity of studies on the subject (Donoso, Rudzki, Shadbolt, $\&$ Bailey, 2003) and the growing relevance of cooperatives to the Brazilian balance of trade.

Within these guidelines, this study aims to identify and describe the possible impacts of internationalization and diversification strategies on the results of agricultural cooperatives in Parana through the operationalization of the following specific goals: a) to identify and characterize the agricultural cooperatives of Parana involved in international activities; b) to outline the internationalization strategies of the cooperatives under study; c) to identify and characterize the eventual diversification activities in the internationalization of the cooperatives under analysis; d) to identify and characterize the factors that facilitate and hinder the internationalization strategies and the resulting diversification process of the cooperatives; and, e) to describe the possible impacts of the internationalization and diversification strategies on the results of the cooperatives involved in international activities. 


\section{COOPERATIVISM AND THE COOPERATIVES}

In this study, a co-operative is "an autonomous association of persons united voluntarily to meet their common economic, social and cultural needs and aspirations through a jointly-owned and democratically-controlled enterprise" (Aliança Cooperativa Internacional [ACI], 2006). For a better understanding of the concept of cooperatives in Brazil, it is important to point out that one of the biggest challenges facing cooperatives lies in operationalizing their unique democratic management model: one member, one vote (Waack \& Machado, 1999), which sets them apart from ordinary businesses. There is another unique characteristic: the bidimensionality of the cooperative, where the association of people is concerned with social responsibility and the enterprise is the sum of its capital. In other words, the member plays a double role: at the same time he is the client and the owner of the cooperative. As a client, a member wants the highest price; as an owner, he wants the best possible economic result. Thus, cooperatives operate in a bidimensional context, i.e., business and social.

Zylbersztajn (1994) noted that small and large cooperatives tend to reorganize their structures in order to allow a proper agency which can facilitate the formation of alliances and cooperation between cooperatives or other strategic partnerships within and outside the country. These new structures, continues the author, are contractual arrangements that enable efficient performance in demanding markets - in this way, the problem of ownership and control, the high costs of trading, and other problems, are minimized. Particularly in the case of internationalization, Novkovic (2007) argued that the international presence of cooperatives is intensified due to competitive pressures. In other words, successful cooperatives are those that adopt several strategies to reduce the impact of the governance structure, as observed by Zylbersztajn above.

\section{INTERNATIONALIZATION}

The internationalization of agricultural cooperatives, seen as the process of growing involvement in outward international activities (Welch \& Luostarinen, 1988), is a world tendency and studies claim it is one of the main challenges faced by cooperatives (Donoso et al., 2003). Existing theories in the field of international business demonstrate the complexity involved in the internationalization process of companies, even though most of them are multinationals. Multiple definitions are offered, varying according to assumptions, aggregation levels and the analysis perspective of the phenomenon. In short, each theory in particular assumes specific analysis criteria that may point out different entry possibilities for the same company.

Starting with the assumption that internationalization requires coherent long-term decisions and considerable assets, the Federation of Danish Cooperatives (FCD, 2000) considers a cooperative to be international when at least one of four internationalization strategies is adopted: exports, alliances, direct investments and organization of a transnational cooperative. In fact, in the Danish model, cooperatives cooperate with each other to become more competitive, and mergers appear as an alternative to cope with the giant companies in the industry while supporting the achievement of their major objective which is to obtain profit and to survive in the market (Karantininis, 2004). ArlanFoods, for instance, is the largest dairy cooperative in the world and is the result of the merger of Danish MD-Foods and Swedish Arla in 2000. This trend is observed among large national cooperatives and transnational strategic alliances as a means to gain economy of scale vis-à-vis global market demands (Nielsen, 2000).

According to Cook (2000), there are four basic competitive strategies to be considered by companies in the agricultural sector, including cooperatives, when analyzing the possibility of internationalizing their business: imports, exports, direct foreign investment and commercial relationships. After making a study of New Zealand cooperatives, Donoso, Shadbolt and Bailey (2004) developed a new model 
that describes six strategies for entrance to the internationalization process: exports (direct and indirect), direct foreign investment (joint ventures and wholly owned ventures), sourcing overseas, knowledge agreements (licensing, research and development), strategic alliances and transnational cooperatives. Although limited in its empirical base, the latter model allowed the researchers to organize entrance strategies not only for the cooperatives under study but also for cases found in literature. Suppliers of commodities have been stepping up their search for sourcing opportunities in a wide variety of markets in order to reduce transaction costs (United States Department of Agriculture [USDA], 2002), as can be seen in the commercial relationship and overseas sourcing strategies proposed in the above models.

From a macro perspective of the global environment, Birchall (2005) suggested two opposite strategic alternatives, in which the cooperative principles would still be preserved: (i) to think locally and act globally: large cooperatives act globally while expanding beyond national borders through joint ventures, mergers and acquisitions; they think locally while convincing the community that their needs will not be neglected and, in addition, offering them incentives to comply with the international demand, such as providing credit lines at preferential rates; and, (ii) to think globally and act locally: in order to be collectively large enough to neutralize global competition through the development of customized solutions to local demands, small cooperatives remain under local control, developing federated representation structures and shared services rather than adopting more aggressive growth strategies.

Although a federation is a traditional way to get advantages of size and location, agricultural cooperatives may not obtain the necessary authority and control to deal with the dynamics of globalization. An alternative suggested by Birchall (2005) would be the formation of transnational alliances with decentralized structure. According to Bialoskorski (2003), these alliances are often made in European cooperatives. In Brazil, however, despite the possible commercial and economic benefits that transnationalization may offer, cooperatives involved in internationalization processes prefer to expand either by establishing representation offices in several countries or by merging with domestic companies.

Brazilian agricultural cooperatives are participants in a large portion of the country's exports, and are apparently satisfied with the role of horizontal coordinators of a wide range of individual suppliers to the international originator companies. Under these circumstances, Zylbersztajn (2002) proposed to overcome the tariff escalation that follows higher aggregate value of the products in several countries, through the introduction of intercooperatives or international alliances activities. "Brazilian cooperatives have not identified the potential of strategic associations outside of Brazil regarding the industrialization of the product exported from Brazil" (Zylbersztajn, 2002, p. 17). In addition to reducing the level of competitiveness, the added value product tends to find a consumer less sensitive to price and more willing to exploit the attributes of the industrialized product. Furthermore, Zylbersztajn (2002) argued that the success of Brazilian cooperatives in the international arena has led them to adopt strategies once disregarded, such as: food sanity and quality control, international consumer trends and issues associated with international protectionism. While not exhausting all alternatives of internationalization strategies, the maintenance of competitive advantage vis-à-vis the gradual emergence of innovative organizational arrangements of cooperatives should be mentioned. Nilsson (1999) suggested that to achieve above average performance by implementing the classic business strategy of sustainable competitive advantage to innovative organizational arrangements, cooperatives are positioned in one of Porter's (1989) generic strategies, as shown in Table 1: 
Table 1: Organizational Arrangements vis-à-vis Porter’s Generic Strategies

\begin{tabular}{|c|c|}
\hline $\begin{array}{c}\text { COOPERATIVE } \\
\text { ORGANIZATIONAL ARRANGEMENT }\end{array}$ & COMPETITIVE STRATEGY \\
\hline TRADITIONAL COOPERATIVE & COST LEADERSHIP (economies of scale) \\
\hline $\begin{array}{c}\text { COOPERATIVE WITH OUTSIDE } \\
\text { INVESTORS }\end{array}$ & $\begin{array}{c}\text { DIFFERENTIATION (capital for high } \\
\text { investments) }\end{array}$ \\
\hline $\begin{array}{c}\text { COOPERATIVE WITH INVESTORS- } \\
\text { MEMBERS }\end{array}$ & FOCUS (capital is limited to niches) \\
\hline
\end{tabular}

Source: adapted from Nilsson (1999, p. 463).

To this end, the outlining of outward internationalization strategies adopted by Parana's agricultural cooperatives in this study was based on the model proposed by the behavioral theory of internationalization of Uppsala (Johanson \& Vahlne, 1977, 1990), which supports entry into new markets in sequential stages of internationalization that are developed in a chain of growing involvement abroad, interposed by the contingency theory (Donaldson, 2006). A good part of the literature adopts a contingency approach to explain issues related to strategic choice and organizational changes (Bertero, 2006), suggesting that companies adapt to ever-changing environments. From this point of view, the achievement of organizational goals depends on the ability of the company to adapt its strategy to the conditions of the environment in which it operates (Donaldson, 2006; Fry \& Smith, 1987; Roth \& Morrison, 1992).

Although the cooperative system was built to provide support for the families of agricultural producers, environmental, domestic and international changes have influenced the markets in which the cooperatives operate. Demands for different services, products and structures indicate the need to adapt to new alternatives. The greatest challenge for cooperatives lies in establishing priorities among the many different goals of their members, which are sometimes in conflict with one another. There is a need to balance the interests of members with the competitive market dynamic (USDA, 2002), in addition to observing a correspondence between internationalization strategy and governance structure, the attitude towards risks and losses and the situation of the cooperative's capital (Petersen, 2004). The interest of the members in internationalization activities is based on the results that can be achieved from the operations in external markets.

\section{INTERNATIONALIZATION OF COOPERATIVES - MOTIVATIONS AND ADVANTAGES}

The reasons behind the motivation for internationalization of agricultural cooperatives are generally the same as those found in any other form of organization (FCD, 2000). Specifically, internationalization in the cooperative sector is considered one of the most promising ways of accessing new markets and obtaining sustainable economic success (Theuvsen \& Ebneth, 2005). As a consequence, a great motivation for the segment is to reach economies of scale (Donoso et al., 2003). The very fact of being a cooperative offers advantages inherent to its nature, which tends to encourage internationalization. Along with other possibilities, potential members overseas may be attracted to the loyalty and solidarity that exists between members, the traceability of products and joint interests. Although there are huge differences between countries, there are many basic shared attributes to cooperatives no matter where they are located (FCD, 2000).

Seipel and Heffernan (1997) identify other advantages in working with cooperatives: end consumers and farmers have guaranteed the consistent supply of high quality products; cooperatives are seen as ethical and trustworthy business partners; cooperatives can be exclusively qualified to fill local and regional market niches; and they can also reduce concerns over the safety and quality of food products. 
Agricultural cooperatives in the United States, aware of these advantages, seem to be developing global strategies based on three self-proclaimed strengths: access to the supplier of the raw product; reputation for quality and supply guaranteed; and permanent innovation for the highly competitive industries of the segment (Cook, 2000).

On the other hand, the governance structure of Brazilian cooperatives in the States of Minas Gerais and São Paulo was investigated by Antonialli (2000) and Cruzio (1999) and their findings point to the low attendance of members at general assemblies, power centralization, lack of administrative competency of directors, slow decision making process and lack of long term planning, all of which suggest a lack of ethics and practices that are not wholly trustworthy.

\section{Product Diversification In InTERNATIONAL MARKETS}

The premise of this study is that diversification involves processes of adding value to the production of agricultural cooperatives, the development of new products or new business matrices in order to penetrate further into or develop new accesses to international markets. In the empirical phase of the research, identification and characterization of activities for diversification for the internationalization of agricultural cooperatives was based on Ansoff's typology (1957): vertical diversification (integration), horizontal diversification (related) and lateral diversification (unrelated). In spite of the relevance of product diversification strategies to reach new markets, literature on internationalization has had little to say on the subject.

Donoso et al. (2003) pointed out that the future of cooperatives depends on the ability of their managers to create a structure to match competition by offering multiple commodities and higher value products on a global basis. However, the cooperative segment has traditionally concentrated on the sale of unprocessed products or products with a low level of processing. More recently, according to Cobia (as cited in Donoso et al., 2003), cooperatives have sought greater vertical integration in order to increase control of the production chain right up to the final retail consumer, at the international level as well. Cooperatives that remain in the commodity business, concentrating on holding the bargaining power of their members, have limited possibilities for growth, whereas those who seek greater margins through differentiation of products, will find greater rewards down the business chain (O'Connor \& Thompson, 2001).

Nevertheless, the investigation carried out by Saes, Silva and Lemes (2005) disclosed the case of poor vertical integration and diversification performance of a Brazilian cooperative settled in the northern area of the State of Parana. The cooperative established a diversification strategy based exclusively on contingent factors and local demands, which proved to be inefficient since the retail market configuration was not taken into consideration.

Specialized literature states that cooperatives should place themselves closer to the end consumer and reach higher levels in the value chain where there is greater profitability (Donoso et al., 2003). Carlos Marés, president of the Far South Regional Development Bank [BRDE], is in favor of product diversification and says that "those who produce commodities and do not add value to their production are absolutely subject to the market" (Anonymous, 2006, p. 9). The main opportunities for creating value through diversification will come, according to Grant (2002), through the full use of a company's resources and competencies.

The international market for higher value products has grown with the dynamic of the globalized economy. Coltrain, Barton and Boland (2000) pointed out three main market forces that motivate product differentiation: (i) increased consumer demand for products related to health, nutrition and convenience; (ii) efforts of food processing companies to improve their productivity; and, (iii) technological advances that enable cooperatives to produce what consumers and food processing 
companies wish. Thus, the focus of production becomes the end consumer rather than only the production of commodities.

According to Ferreira and Braga (2004), the high number of cooperatives which run at a loss or with low profits from their main activity appears to encourage diversification as a new strategic posture aimed at minimization of risks and impulsion of revenues. The authors carried out their study investigating 64 agricultural cooperatives in the States of Minas Gerais and São Paulo and noticed that most of the cooperatives adopt diversification of activities led by internal and external factors. Internally, diversification is most closely linked to satisfying the interests of the members of the cooperative and to achieving improved financial results. External motivation is mostly found in the drive to satisfy the needs of the community in which the cooperative is active and to take advantage of entrepreneurial opportunities that arise.

On the other hand, Hendrikse and Oijen (2002) concluded in their study on the Dutch market that venture capital companies have higher degrees of related and unrelated diversification than cooperatives and that the cooperatives that diversify place more emphasis on unrelated diversification. In another study by the same authors (Oijen \& Hendrikse, 2002), the influence of the governance structure of 118 Dutch cooperatives and corporations on unrelated product diversification and on financial outcomes was analyzed. Results suggest that governance structure does matter since: (i) cooperatives are less diversified than corporations; (ii) cooperatives have a higher ratio of unrelated diversification to total diversification than corporations; and, (iii) cooperatives' performance are negatively influenced by unrelated diversification while corporations have no influence at all. However, different institutional environments may affect the governance structure in different ways.

In spite of the representativeness of the cooperative segment in the Brazilian balance of trade and the high investments expected for the sector which follow the trend to diversify production through added value processing, no specific literature was found that deals with diversification by cooperatives (Oijen \& Hendrikse, 2002) as part of their internationalization strategy; we hope that this study describes the possible associations.

\section{INTERNATIONALIZATION RESULTS}

A central theme for debate among academics has been the impact of internationalization on the financial results of the company. The experience of thousands of companies that were studied would seem to suggest a positive result (Sullivan, 1994). Thus, the result of a company may be highly correlated with its degree of internationalization; according to Geringer, Beamish and Costa (1989), it is not always positive since, after a certain level of internationalization has been reached, the higher the number of markets the company operates in, the higher the costs of managing the geographic distances, which ends up reducing profits.

For the cooperatives, internationalization is one of the most promising ways to gain new markets and obtain sustained economic success (Theuvsen \& Ebneth, 2005). As the cooperative itself does not seek profit, but rather is essentially a provider of services for its members, seeking better results may be the reflex of the need to maximize benefits for its members instead of maximizing profits. In this situation, as Bialoskorski (1995) and Bialoskorski, Marques and Neves (1995) pointed out, the cooperative should act from the outside of the organization according to its economic market knowledge and business efficiency, and also from the inside of the organization, distributing the fruits to its members at the end of the fiscal year, proving its social effectiveness. We cannot ignore the fact that the member is both the user and the owner of the cooperative.

In the specific case of cooperatives, Ebneth and Theuvsen (2005) suggested that the degree of internationalization and financial performance are directly linked to the capacity of managers to solve the problems of ownership, horizon, control, portfolio, governance and origin. In effect, the principles 
of ownership, control and benefits are what make the cooperative different from a venture capital company. These differences may have implications concerning the financial performance of the cooperative, especially profitability, capital structure, liquidity and the efficiency of assets. The work of Hardesty and Salgia (2004) compared the financial performance of agricultural cooperatives with that of the industrial sector capital venture companies in the United States, and the data analysis from 1991-2002 period shows that there are no consistent differences between the financial performance of cooperatives and that of venture capital companies.

Internationalization can equally enhance the performance of different companies in related activities, as the differences of supply and demand and factors concerning international markets help reduce risks and increase more stable returns (Hitt, Hoskisson, \& Ireland, 1994). Companies can also benefit from internationalization with unrelated diversification, either through scale or scope economies (Hitt, Tihanyi, Miller, \& Connelly, 2006). Empirical research demonstrates that companies which operate internationally have better results through unrelated diversification (Geringer et al., 1989). Other studies show that companies with high diversification levels are less profitable than those with lower diversification levels (Montgomery, 1994). On the other hand, Grant (2002) analyzed over a hundred academic studies and concluded that it is not possible to determine whether diversification improves profitability or related diversification surpasses the performance of unrelated diversification.

Due to the scarcity of data on cooperatives, Theuvsen and Ebneth (2005) suggested that the construct for this specific population should be prepared with only three internationalization variables: international sales index, network expansion index and a combined index with both of these variables. When objective financial indicators are not available or access to them is restricted, Brouthers (2002) recommended utilizing subjective indicators of assessment of results. These indicators, given in the opinion of managers, allow the evaluation not only of financial performance but also of other types of performance; in the case of cooperatives, non-financial indicators may be useful for revealing results concerning the social aspects of the business. A similar methodology was used by Peterson and Anderson (1996) in their study about the benefits for members of North American cooperatives due to the different strategic choices made by their managers.

Therefore, for this study, the results of the internationalization process are derived from financial and non-financial indicators, influenced by involvement in international activities which reflect the business efficiency and social efficacy of the agricultural cooperative. The result indicators were obtained from the opinion of the cooperative representative, who evaluated the cooperative results subjectively.

\section{METHODOLOGY}

Four analysis variables were established for research and for the theoretical-empirical foundation: internationalization; diversification; factors which facilitate and hinder internationalization and diversification; and results. The relationship hypothesized among these variables suggests that the internationalization strategy of the cooperatives may or may not include diversification of production. No matter what the situation, external and internal factors can intervene either to facilitate or to hinder internationalization and diversification, which in turn can affect results. These factors are seen as elements of the organization environment which may produce a direct or indirect impact on decisions involving internationalization or diversification made by the top management of agricultural cooperatives.

The empirical research consisted of the application of a survey with triangulation of data (Eisenhardt, 1989). The sample for this stage was probabilistic and included all the agricultural cooperatives in the State of Parana involved in outward international activities. To avoid biases in the analysis, the population representing the theme of research comprises 28 cooperatives which operate within a significant level of internationalization. A structured questionnaire was distributed with 
ordinal and interval scales according to the type of question. From the 20 questions, four were prepared with a five-point Likert scale ranging from I totally agree to I totally disagree and from very important to not important.

Twenty-one out of the 28 cooperatives returned the completed questionnaires, 19 of which $(67.9 \%)$ were valid. The respondents of the valid questionnaires have the following profile: five are directors or superintendents of their cooperative, eight are managers and six are traders, market analysts or coordinators. Due to the small population of the study, the data collected in the survey were subjected to non-parametric statistical analysis with the application of the chi-square test, Spearman's bivariate correlation and the Kruskal-Wallis test. For the ranking there were not a sufficient number of cases to apply the Median test. The significance level of 0.05 was used in all tests.

\section{ANALYSIS}

A great amount of data was collected and analyzed. The considerations that follow are an attempt to answer the key questions of this study.

\section{Characterization of Agricultural Cooperatives in Parana}

Agricultural cooperatives from all over the state are included in the sampling for this study. However, the western and northwestern regions are more widely represented. Only one of the cooperatives is a federation of cooperatives; all the others are first-degree cooperatives.

The total average revenue for 2006 is of $R \$ 536.6$ million, ranging from $R \$ 44.5$ million to $R \$$ 2,662.5 million per year. The size rating based on annual revenues finds five small, nine middle-sized and five large cooperatives. The average number of members is 4,224 , and the average number of employees is 1,744 .

The business matrix configuration of the cooperatives confirms the agricultural inclination of the State and emphasizes the importance of diversification as a way of offering new alternatives to the farmer, reducing risks and boosting income. The revenue of $63.2 \%$ of the sample originates from at least three different matrices.

The internationalization activities for most of the cooperatives account for less than $30 \%$ of their total business income, which is below the percentage considered ideal by the segment. Spearman's rank correlation coefficient indicates that total revenue is statistically more significant with the number of employees $(p=0.000)$ than with the amount of cooperative members $(p=0.020)$ (Table 2$)$, suggesting that cooperatives' revenue is expanded when adopting diversification strategies which require mass labor to perform industrialization processes.

Table 2: Agriculture Cooperatives of Parana - Association among Total Annual Revenue, Members and Employees

\begin{tabular}{|l|l|r|r|r|}
\hline Spearman's rho & \multicolumn{1}{|c|}{ Members } & Employees & \multicolumn{1}{c|}{$\begin{array}{c}\text { Total Annual } \\
\text { Revenue }\end{array}$} \\
\hline MEMBERS & $\begin{array}{l}\text { Correlation } \\
\text { Coefficient }\end{array}$ & 1.000 & 0.412 & $0.530(*)$ \\
\cline { 2 - 5 } & Sig. (2-tailed) &. & 0.079 & 0.020 \\
\cline { 2 - 5 } & $\mathrm{N}$ & 19 & 19 & 19 \\
\hline
\end{tabular}




\section{(conclusion)}

Table 2: Agriculture Cooperatives of Parana - Association among Total Annual Revenue, Members and Employees

\begin{tabular}{|l|l|r|r|r|}
\hline Spearman's rho & \multicolumn{1}{|c|}{ Members } & \multicolumn{1}{c|}{ Employees } & \multicolumn{1}{c|}{$\begin{array}{c}\text { Total Annual } \\
\text { Revenue }\end{array}$} \\
\hline \multirow{5}{*}{ EMPLOYEES } & $\begin{array}{l}\text { Correlation } \\
\text { Coefficient }\end{array}$ & 0.412 & 1.000 & $0.842(* *)$ \\
\cline { 2 - 5 } & Sig. (2-tailed) & 0.079 &. & 0.000 \\
\cline { 2 - 5 } & $\mathrm{N}$ & 19 & 19 & 19 \\
\hline \multirow{5}{*}{ TOTAL REVENUE } & $\begin{array}{l}\text { Correlation } \\
\text { Coefficient }\end{array}$ & $0.530(*)$ & $0.842(* *)$ & 1.000 \\
\cline { 2 - 5 } & Sig. (2-tailed) & 0.020 & 0.000 & 19 \\
\cline { 2 - 5 } & $\mathrm{N}$ & 19 & 19 &. \\
\hline
\end{tabular}

* Correlation is significant at the 0.05 level (2-tailed).

** Correlation is significant at the 0.01 level (2-tailed).

Source: research data.

\section{Internationalization Strategies}

Internationalization strategies do not go beyond the early stages of involvement overseas. A hundred percent and $57.9 \%$ of the sample, respectively, adopt direct and indirect exports modes of entry to serve external markets, mainly Western Europe, Asia and Eastern Europe. Only a fraction of the cooperatives (31.6\%) are involved in inward internationalization.

The periodicity in which cooperatives of the sample internationalize their activities expresses their preference to operate on a constant basis $(52.6 \%)$ even when external factors temporarily reduce the profitability of the transactions. Despite the fact that the modes of entry indicate low involvement abroad, the sector believes internationalization is crucial for growth and intends to increase its share of international sales to improve revenues.

The effects of the strategic planning of Parana's cooperative system to increase value added processes of agricultural products can be seen in the types of products that are traded overseas, bearing in mind that only a small number of cooperatives are restricted exclusively to exporting commodities (Table 3). Furthermore, the number of employees is higher in cooperatives that require mass labor to industrialize their products (Table 4).

Table 3: Agriculture Cooperatives of Parana - Type of Products Traded Overseas - 2006

\begin{tabular}{|c|c|c|}
\hline TYPE OF PRODUCTS & COOPERATIVES & \% \\
\hline Commodities & 6 & 31.6 \\
\hline Semi-industrialized and industrialized & 7 & 36.8 \\
\hline $\begin{array}{c}\text { Commodities, semi-industrialized and } \\
\text { industrialized }\end{array}$ & 6 & 31.6 \\
\hline TOTAL & 19 & 100.0 \\
\hline
\end{tabular}

Source: research data. 
Table 4: Agriculture Cooperatives of Parana - Comparison among Type of Products, Members and Employees

\begin{tabular}{|l|c|c|c|}
\hline & & $\mathrm{N}$ & Means \\
\hline MEMBERS & Commodities & 6 & 9.50 \\
\hline & $\begin{array}{c}\text { Semi-industrialized and } \\
\text { industrialized }\end{array}$ & 7 & 6.29 \\
\hline EMPLOYEES & $\begin{array}{c}\text { Commodities, semi-industrialized } \\
\text { and industrialized }\end{array}$ & 6 & 14.83 \\
\hline & Total & 19 & 4.17 \\
\hline & $\begin{array}{c}\text { Commodities } \\
\text { industrialized }\end{array}$ & 6 & 11.43 \\
\hline & $\begin{array}{c}\text { Commodities, semi-industrialized } \\
\text { and industrialized }\end{array}$ & 6 & 14.17 \\
\hline & Total & 19 & \\
\hline
\end{tabular}

Source: research data.

Statistical Tests (a, b)

\begin{tabular}{|c|c|c|}
\hline & Members & Employees \\
\hline Chi-Square & 7,523 & 10,188 \\
\hline df & 2 & 2 \\
\hline Asymp. Sig. & 0.023 & $0 ., 006$ \\
\hline
\end{tabular}

a Kruskal Wallis Test.

b Grouping Variable: type of products.

\section{Product Diversification Strategies in Internationalization}

The development of customized products from the existing portfolio $(42.1 \%)$ and the development of new business matrices to meet international demand (42.1\%) are the diversification strategies most frequently adopted by the cooperatives that are already involved in added value processes. Nevertheless, cooperatives that exclusively export commodities (36.8\%) have been carrying out studies to start industrialization processes in order to serve external markets.

Proximity to the international customer due to the offer of differentiated products is reflected in the entrance strategies to overseas markets: an expressive portion of direct exports and all imports are from cooperatives which export products which have some degree of added value. This characteristic has no implications in the periodicity in which cooperatives internationalize since the export behavior remains unchanged in spite of the type of product that is traded.

Regarding the consolidation of the brand name, the transactions in which the cooperative brand reaches only the distribution channel abroad prevail (69.2\%). There are fewer cases in which, at the same level of frequency (38.5\%), the brand of the cooperative reaches the final customer or in which the product comes out with the customers' or distributors' brand.

The formation of strategic alliances to increase efficiency and competitiveness finds two types of behavior in the agricultural cooperatives. While most of the cooperatives of the sample have interest in this type of partnership (52.6\%), half of these favor venture capital companies and the other half, which consists primarily of small commodities exporters' cooperatives, focus on cooperation among cooperatives in Brazil or abroad, which is one of the cooperative principles and facilitates commercial interaction as their business outlook is similar. 
The access to distribution channels abroad is a priority in the formation of business partnerships (57.9\%). Secondary goals are the access to new technologies and complementation of stages of industrialization processes as a means to reduce or postpone investment in new plants.

\section{Factors which Facilitate and Hinder Internationalization}

The factors that encourage cooperatives to internationalize their activities are very similar to those which lead venture capital companies overseas. Increased revenues, profitability and gains for the cooperative and its members, along with better trade prices, figure as the main motives. There are also factors that point out the need to sell in different markets which, in addition to reducing the risks of operating in a single market, ensures the survival of the farmer, the main supply agent of the cooperative. Outlined in a minor degree of relevance, the international market provides access to new sources of information and distribution channels, as well as the acquisition of core competencies to technologically innovate the cooperative.

Not all motivations are considered analogously. The Kruskal-Wallis test indicates that cooperatives with eventual internationalization activities, which are essentially exporters of commodities, place more emphasis on the stagnated or saturated domestic market $(\rho=0.041)$ as an incentive to internationalize. Larger cooperatives confer less importance to the reduction of risks $(\rho=0.028)$, whereas cooperatives that trade both commodities and industrialized products abroad attribute more importance to this incentive.

The adoption of diversification strategies to meet the requirements of the international market is motivated mainly by the opportunity to create alternative gains for members and reduce the risks of the agricultural business, placing special interest on financial performance on the part of the cooperative member. Spearman's rank correlation coefficient indicates a significant statistical association $(\rho=0.004)$ between alternative gains and better trade prices. However, meeting international demand for differentiated products has a significant statistical association $(\rho=0.002)$ with the idle productive capacity of the cooperative.

Obtaining better trade prices through diversification is more relevant to cooperatives with more frequent international transactions, and the possibility of adopting different strategies in the international market is more important for cooperatives that combine export of commodities with industrialized products.

Internationalization is mainly facilitated for cooperatives that have food safety certifications and present the same technological level as developed markets and have access to distribution channels abroad. Little importance is attributed to geographical proximity and language differences, which are referred to as psychic distance factors by the Uppsala School.

The periodicity of commercialization and the size of the cooperative do not interfere in the assessment of the facilitators. However, those who exclusively export commodities place more emphasis than other cooperatives on their relationships with exporters in Brazil $(\rho=0.037)$ and on culture and language similarities with the country they are trading with $(\rho=0.016)$.

Internationalization is mostly hindered by external factors, including currency exchange policy, the extra costs of doing business in Brazil due to poor logistics and fiscal structure, barriers, bureaucracy and legal matters pertaining to the internationalization process. Less importance is placed on internal factors concerning the competitiveness of the cooperative, such as adaptation of the structure and the cost of adapting products to meet the demands of the external market, lack of regularity of production and the complexity of managing international operations.

When considering the periodicity of international trade, there is no difference in the difficulties experienced by the cooperatives. However, larger cooperatives place less importance on adaptation of structure to meet international requirements (Kruskal-Wallis test has $\rho=0.007$ ), which is not the case 
for exporters of commodities $(\rho=0.004)$, who also consider the lack of regularity of production $(\rho=$ $0.024)$ and the costs of marketing strategies to access external markets $(\rho=0.024)$.

\section{Results of Internationalization Strategies - Description of Impacts}

Internationalization produces positive results for agricultural cooperatives, either from an economic or social perspective. Its residual effects lead to strategic and operational improvements by increasing performance and productivity, which develops competitiveness, strategic flexibility and operational alternatives of the cooperative vis-à-vis the targeted markets. The general assessment of cooperatives concerning internationalization activities is favorable, and members show little resistance to operating in external markets when their interests are being met. The results and general evaluation of internationalization are considered analogically by all cooperatives, irrespective of the periodicity of international trading, size and type of product traded abroad according to the Kruskal-Wallis test results.

The agricultural cooperatives see their revenues increase when they adopt strategies of product diversification geared to international markets, whereas cooperatives that only trade commodities have the lowest averages of revenues and the cooperatives that trade commodities and added value products have higher averages (Table 5). In other words, the size of the cooperative is influenced by the types of products traded abroad.

Table 5: Agriculture Cooperatives of Parana - Comparison between Type of Products Traded Abroad and Average Annual Revenue 2006

\begin{tabular}{|c|c|c|c|}
\hline TYPE OF PRODUCTS & COOPERATIVES & $\begin{array}{c}\text { AVERAGE } \\
\text { ANNUAL } \\
\text { REVENUE 2006 }\end{array}$ & STANDARD DEVIATION \\
\hline Commodities & 6 & $\mathrm{R} \$ 179,198,990.83$ & $\mathrm{R} \$ 135,702,639.25$ \\
\hline $\begin{array}{c}\text { Semi-industrialized and } \\
\text { industrialized }\end{array}$ & 7 & $\mathrm{R} \$ 321,214,385.28$ & $\mathrm{R} \$ 216,944,194.11$ \\
\hline $\begin{array}{c}\text { Commodities, semi- } \\
\text { industrialized and } \\
\text { industrialized }\end{array}$ & 6 & $\mathrm{R} \$ 1,145,474,180.67$ & $\mathrm{R} \$ 752,36, .399 .70$ \\
\hline TOTAL & $\mathbf{1 9}$ & $\mathbf{R} \$ \mathbf{5 3 6 , 6 5 9 , 9 8 5 . 5 8}$ & $\mathbf{R} \mathbf{6 0 1 , 8 5 9 , 1 2 3 . 3 6}$ \\
\hline
\end{tabular}

Source: research data.

Statistical Tests $(a, b)$

\begin{tabular}{|c|c|}
\hline Chi-Square & 12,677 \\
\hline $\mathrm{df}$ & 2 \\
\hline Asymp. Sig. & 0.002 \\
\hline
\end{tabular}

a Kruskal Wallis Test

b Grouping Variable: type of products

The Kruskal-Wallis statistical test indicates that the revenues of cooperatives do not depend on how often they internationalize their activities $(\rho=0.285)$. However, the more diversification strategies are adopted, the higher the revenues of the cooperative $(\rho=0.013)$.

\section{FinAL CONSIDERATIONS}

While there have been many findings of this research, some deserve to be given special attention. First, the positive effects of internationalization are indisputable when considering the social and 
economic results of the cooperatives. Meanwhile, diversification of products addressed to foreign markets which did not reveal its magnitude at first, has acquired a significant proportion in this study. Evidence points to the importance of added value products to increasing the revenues of cooperatives; the nine largest revenues and thirteen cooperatives classified as midsize and large are involved in the international trade of semi-industrialized and industrialized products. Besides the imperative need to break protectionist barriers imposed on commodities, agroindustrialization increases the overall competitiveness of the cooperatives and allows the adoption of differentiation strategies with more profitable products. It is not possible to conceive the growth of cooperatives without agroindustrialization processes and, curiously, without the maintenance of exports of commodities as well.

Second, the low international involvement of the cooperatives can be identified by the selected modes of entry and the modest participation of international sales on total sales, especially for the large cooperatives, which mostly have an international commercialization rate below $25 \%$ of the total. Although inward internationalization and direct exports are carried almost exclusively by cooperatives of a larger size, which deal with added value products, the increase in international sales depends greatly on the effects of external factors over the adoption of internationalization strategies by the cooperatives. Therefore, the increase in international sales is clearly linked to the problems of the environment, even for larger cooperatives that carry diversified products in their portfolios.

Third, contingency factors of domestic and international markets impact on the behavior of the cooperatives that present eventual internationalization activity. At the same time that this attitude does not bring major consequences to revenues as the tonic is the quest for better conditions of trade, it does commit the adoption of internationalization strategies of greater complexity that could leverage the performance, productivity and therefore the opportunities of growth for those cooperatives, mostly small exporters of commodities. Aware of the competitive world scenario, these cooperatives have been looking for alternative industrial processes that increase product value. However, they run into technical and financial difficulties that have been overcome by cooperation among cooperatives and closer relationships with exporting entities. Related institutions, attentive to this trend, may develop technical support and market programs to diminish specific needs of the segment without interfering with cooperative principles.

Finally, internal parameters of cooperatives and their complex relationship with the interests of members have a significant effect on the internationalization process, in which the priorities of the members may be comparatively relevant to market conditions and their competitive dynamic. This condition suggests important issues for future studies on Brazilian cooperatives. This investigation has raised other related topics that may be considered for future inquiry:

. One of the cooperative principles established by the International Co-operative Alliance advocates cooperation among cooperatives. Inter-cooperation in the state of Parana is preferred by smaller cooperatives which exclusively export commodities to the detriment of other possibilities for cooperation on a larger scale. The aversion of middle sized and large cooperatives and the alternatives they prioritize need to be better understood. Are non-cooperatives alliances being preferred?;

Agroindustrialization carried out exclusively does not appear to produce the same results as those achieved in internationalization strategies which combine commodities with added value products. There are indications that the combined arrangement provides higher revenues to agricultural cooperatives and better technical and operational conditions to tackle the opportunities that offer internationalization and diversification. A more comprehensive study may identify the existing relationship;

. The adoption of low involvement internationalization strategies does not find support in the size, types of products or available structures of different cooperatives. While access to overseas markets is seen as a challenge to be overcome, no cooperative goes beyond the direct export strategy for entry into external markets. Why?; 
In the State of Parana, only just over a third of the agricultural cooperatives internationalize their activities. The inclusion of agricultural cooperatives that limit their operations exclusively to the domestic market in future research could offer a more comprehensive picture about the conditions that encourage or restrict their access to international markets.

The singularities of the cooperative organization, the external factors that impact the internationalization process of the Brazilian cooperatives, the lack of research in this area in Brazil, and the preliminary findings of this study, will hopefully encourage future academic investigation.

\section{REFERENCES}

Aliança Cooperativa Internacional. (2006). Statement on the co-operative identity. Retrieved December 19, 2006, from http://www.ica.coop/coop/principles.html

Anonymous. (2006). Impulso ao desenvolvimento econômico e social [Entrevista com Carlos Frederico Marés de Souza Filho]. Paraná Cooperativo, 22(2), 6-9.

Ansoff, H. I. (1957). Strategies for diversification. Harvard Business Review, 35(5), 113-124.

Antonialli, L. M. (2000). Influência da mudança de gestão nas estratégias de uma cooperativa agropecuária. Revista de Administração Contemporânea, 4(1), 135-159.

Bertero, C. O. (2006). Nota técnica: teoria da contingência estrutural. In S. R. Clegg, C. Hardy, \& W. R. Nord (Orgs.). Handbook de Estudos Organizacionais (Vol. 1, pp. 132-134). São Paulo: Atlas.

Bialoskorski, S., Neto (1995, setembro). Cooperativas: negócios, eficiência e tendências. Anais do Congresso Centenário da Aliança Cooperativa Internacional, Manchester, Inglaterra.

Bialoskorski, S., Neto (2003). Ambiente institucional e estratégias de empreendimentos cooperativos: a identidade cooperativa para o novo milênio. Saberes, (01), Ano 1, 35-50.

Bialoskorski, S., Neto, Marques, P. V., \& Neves, E. M. (1995). A economia do agribusiness cooperativo. Anais do Congresso Brasileiro de Economia e Sociologia Rural, Brasília, DF, Brasil, 33.

Birchall, J. (2005). Co-operative principles ten years on. Review of International Cooperation, 98(2), 45-63.

Brouthers, K. D. (2002). Institutional, cultural and transaction cost influences on entry mode choice and performance. Journal of International Business Studies, 33(2), 203-221.

Coltrain, D., Barton, D., \& Boland, M. (2000). Value-added: opportunities and strategies. Arthur Capper Cooperative Center, Kansas State University, Kansas, USA. Retrieved March 10, 2007, from http://www.agecon.ksu.edu/accc/kcdc/PDF\%20Files/VALADD10\%202col.pdf

Cook, M. L. (2000, August). Cooperatives and globalisation. Proceedings of the Workshop Internacional de Tendências do Cooperativismo, Ribeirão Preto, SP, Brasil, 2.

Cruzio, H. O. (1999). Por que as cooperativas agropecuárias e agroindustriais brasileiras estão falindo? Revista de Administração de Empresas, 39(2), 18-26.

Donaldson, L. (2006). Teoria da contingência estrutural. In S. R. Clegg, C. Hardy, \& W. R. Nord (Orgs.). Handbook de Estudos Organizacionais (Vol. 1, pp. 104-131). São Paulo: Atlas. 
Donoso, I., Rudzki, R., Shadbolt, N., \& Bailey, W. (2003). The internationalization of agricultural cooperatives: critical factors in development. Agribusiness Perspectives Papers 2003 (Paper No 61), Massey University, New Zealand. Retrieved January 29, 2007, from http://www.agrifood.info/perspectives/2003/Donoso.html

Donoso, I., Shadbolt, N., \& Bailey, W. (2004, June). The internationalization of agricultural cooperatives: a source of conflict? Proceedings of the Annual World Food and Agribusiness Symposium and Forum, Montreux, Switzerland, 14.

Ebneth, O., \& Theuvsen, L. (2005, June). Internationalization and financial performance of cooperatives: empirical evidence from the European dairy sector. Proceedings of the Annual World Food and Agribusiness Symposium and Forum, Chicago, Illinois, USA, 15.

Eisenhardt, K. M. (1989). Building theories from case study research. The Academy of Management Review, 14(4), 532-550.

Federação das Cooperativas Dinamarquesas. (2000). Transnational co-operatives: perspectives for admission of members abroad and cross-border mergers. Retrieved January 8, 2007, from http://www.danskeandelsselskaber.dk/view.asp?ID=11940

Ferreira, G., \& Denardin, V. (2006). Caderno caminhos do campo, agroindústria. Gazeta do Povo Online. $\quad$ Retrieved November 28, 2006, from http://caminhosdocampo.ondarpc.com.br/jornal/conteudo.phtml?id=579119

Ferreira, M. A. M., \& Braga, M. J. (2004). Diversificação e competitividade nas cooperativas agropecuárias. Revista de Administração Contemporânea, 8(4), 33-55.

Fry, L. W., \& Smith, D. A. (1987). Congruence, contingency, and theory building. The Academy of Management Review, 12(1), 117-132.

Geringer, J. M., Beamish, P. W., \& Costa, R. C. da (1989). Diversification strategy and internationalization: implications for MNE performance. Strategic Management Journal, 10(2), 109-119.

Grant, R. M. (2002). Corporate strategy: managing scope and strategy content. In A. Pettigrew, H. Thomas, \& R. Whittington (Eds.). Handbook of strategy and management (pp. 72-97). London: Sage Publications.

Hardesty, S. D., \& Salgia, V. D. (2004, November). Comparative financial performance of agricultural cooperatives and investor-owned firms. Proceedings of the NCR-194 Research on Cooperatives Annual Meeting, Kansas City, Missouri, USA.

Hendrikse, G. W. J., \& Oijen, A. C. J. van (2002). Diversification and corporate governance. (ERIM Report Series ERS-2002-48-ORG), Rotterdam School of Management, Erasmus Universiteit Rotterdam, Rotterdam, Netherlands.

Hitt, M. A., Hoskisson, R. E., \& Ireland, R. D. (1994). A mid-range theory of the interactive effects of international and product diversification on innovation and performance. Journal of Management, 20(2), 297-326.

Hitt, M. A., Tihanyi, L., Miller, T., \& Connelly, R. (2006). International diversification: antecedents, outcomes, and moderators. Journal of Management, 32(6), 831-867.

Johanson, J., \& Vahlne, J. E. (1977). The internationalization process of the firm: a model of knowledge development and increasing foreign market commitments. Journal of International Business Studies, 8(1), 23-32. 
Johanson, J., \& Vahlne, J. E. (1990). The mechanism of internationalization. International Marketing Review, 7(4), 11-24.

Karantininis, K. (2004). Cooperativismo agropecuário. Revista Coplana, 3(16), 20-23.

Lopes, M. R. (2003). Hora de negociar. Agroanalysis - Revista de Agronegócios da FGV, 23(2), 43 46.

Ministério do Desenvolvimento, Indústria e Comércio Exterior, Secretaria de Comércio Exterior. (2007). Exportação de Cooperativas Brasileiras. Retrieved February 10, 2007, from http://www.mdic.gov.br/sitio/interna/interna.php?area=5\&menu=1202\&refr=608

Montgomery, C. A. (1994). Corporate diversification. Journal of Economic Perspectives, 8(3), 163178.

Nielsen, H. H. (2000, August). The fusion process of the Danish milk co-operatives. Proceedings of the Workshop Internacional de Tendências do Cooperativismo, Ribeirão Preto, SP, Brasil, 2.

Nilsson, J. (1999). Co-operative organisational models as reflections of the business environments. The Finnish Journal of Business Economics, (4), 449-470.

Novkovic, S. (2007). R\&D, innovation and networking: strategies for cooperative survival. In S. Novkovic \& V. Sena (Eds.). Cooperative firms in global markets (Vol. 10, pp. 205-232). Oxford, UK: Elsevier Ltd.

O'Connor, J., \& Thompson, G. (2001). International trends in the structure of agricultural cooperatives. (Report RIRDC No 01/06), Kingstone, Australia, Rural Industries Research and Development Corporation.

Oijen, A. A. van, \& Hendrikse, G. W. (2002). Governance structure, product diversification, and performance. (ERIM Report Series ERS-2002-51-ORG). Rotterdam School of Management, Erasmus Universiteit Rotterdam, Rotterdam, Netherlands.

Organização das Cooperativas do Estado do Paraná. (2006). Estudo sobre a evolução das exportações brasileiras, do agronegócio, paranaenses e das cooperativas. (Relatório Técnico 2006). Curitiba, PR, Diretoria Técnica.

Organização das Cooperativas do Estado do Paraná. (2007). Exportações do Brasil, do Paraná e das Cooperativas no ano de 2006. (Relatório Técnico 2007). Curitiba, PR, Diretoria Técnica.

Petersen, S. B. (2004). Cooperatives and the EU enlargement. Federation of Danish Cooperatives, Agriculture Council of Denmark, 2004. Retrieved January 8, 2007, from <http://www.danskeandelsselskaber.dk/view.asp?ID=11940>.

Peterson, H. C., \& Anderson, B. L. (1996). Cooperative strategy: theory and practice. Agribusiness, 12(4), 371-383.

Porter, M. E. (1989). Vantagem competitiva: criando e sustentando um desempenho superior (29a ed.). Rio de Janeiro: Elsevier.

Roth, K., \& Morrison, A. J. (1992). Business-level competitive strategy: a contingency link to internationalization. Journal of Management, 18(3), 473-487.

Saes, M. S. M., Silva, C. L., \& Lemes, L. F. C. (2005, setembro). Cocamar: contornos da crise e vocação estratégica de desenvolvimento regional. Anais do Congresso Brasileiro de História Econômica e $7^{a}$. Conferência Internacional de História de Empresas, Conservatória, RJ, Brasil, 6. 
Seipel, M. F., \& Heffernan, W. D. (1997). The transnational challenge: cooperatives and the global food system. Rural Cooperatives, 64(4), 6-10.

Sullivan, D. (1994). Measuring the degree of internationalization of a firm. Journal of International Business Studies, 25(2), 325-342.

Theuvsen, L., \& Ebneth, O. (2005). Internationalization of cooperatives in the agribusiness: concepts of measurement and their application. In T. Theurl \& E. C. Meyer (Eds.). Strategies for Cooperation (pp. 395-419). Germany: Shaker Verlag GmbH.

United States Department of Agriculture. (2002). Agricultural cooperatives in the $21^{\text {st }}$ century (Cooperative Information Report 60). Washington, DC, Rural Business-Cooperative Service.

Waack, R. S., \& Machado, C. P., Filho (1999, Novembro). Administração estratégica em cooperativas agroindustriais. Proceedings of the Workshop Brasileiro de Gestão de Sistemas Agroalimentares, Ribeirão Preto, SP, Brasil, 2.

Welch, L. S., \& Luostarinen, R. (1988). Internationalization: evolution of a concept. Journal of General Management, 14(2), 34-55.

Zylbersztajn, D. (1994) Organização de cooperativas: desafios e tendências. Revista de Administração da USP, 29(3), 23-32.

Zylbersztajn, D. (2002, outubro). Quatro estratégias fundamentais para cooperativas agrícolas. Proceedings of the Seminário de Política Econômica: Cooperativismo e Agronegócio, Viçosa, MG, Brasil, 14. 


\section{ANNEX 1}

\section{Research about the Internationalization of Agriculture Cooperatives}

Date: $/ 2007$

Cooperative:

Respondent name:

Respondent position:

Time in the cooperative: Time in the position:

1. How is your cooperative classified?

$\square$ First degree

$\square$ Second degree

$\square$ Confederation

2. How many members and employees does your cooperative have?

Members Employees

3. How much was the total cooperative revenue for 2006 ?

$2006-\mathrm{R} \$$

4. How is the cooperative business matrix composed?

(choose as many alternatives as necessary)

$\square$ Agriculture Sector $\%$ total revenue

Which are the main cultures?

$\square \quad$ Meat Sector $\%$ total revenue

Which are the main segments? $\square$ aviculture
$\square$ pig breeding
$\square$ cow breeding
$\square$ sheep breeding
$\square$ other

Goods and raw material sold to members $\%$ total revenue

$\square$ Other $\%$ total revenue 
5. How does your cooperative relate to the international market?

(choose as many alternatives as necessary)

$\square$ Indirect export (trading and agents)

$\square$ Direct export to customer or distributor

$\square$ Subsidiary/Sales Office overseas

$\square$ Licensing

$\square$ Partnerships (joint ventures) with Brazilian or international capital companies

$\square$ Partnerships (joint ventures) with Brazilian or international cooperatives

$\square$ Imports of equipment and technology

Other

6. What are the products your cooperative negotiates overseas?

(choose as many alternatives as necessary)

\section{Commodities:}

Which? $\square$ soybean

$$
\begin{aligned}
& \square \text { corn } \\
& \square \text { wheat } \\
& \square \text { beans } \\
& \square \text { coffee } \\
& \square \text { other }
\end{aligned}
$$

Semi-processed and processed products:

Which? $\square$ dairy products

$\square$ meat products

$\square$ other

7. How often does your cooperative negotiate in the international market?

(choose as many alternatives as necessary)

$\square$ Occasional or sporadic

$\square$ only when there is production surplus

$\square$ only when there are unexpected orders

$\square$ only when international circumstances are more favorable/attractive than the domestic market

$\square$ Continuous, however there are periods in which external factors create obstacles to the negotiation (sanitary factors, exchange factors, etc.) and the cooperative temporarily interrupts its international operations.

$\square$ Continuous, the cooperative maintains the international operations even when external factors (sanitary, exchange, etc.) are not favorable to international business and profit can be temporarily reduced.

Other 
8. How is the participation of international trade forecasted on the total commercialization of the cooperative?

Participation tends to increase

Participation tends to be maintained at the present level

$\square$ Participation tends to decrease

9. How important is international trading to the cooperative growth?

$\square$ very important $\square$ important $\square$ somewhat important $\square$ it is not important

10. What are the three main markets served by your cooperative?

$\square$ North America $\square$ Central America and Caribbean

Western Europe $\square$ Eastern Europe $\square$ Asia

Middle East $\square$ Africa $\quad \square$ Oceania

11. What was the trading basis of the cooperative in 2006 ?

Domestic market - $2006-[\%$ International market - $2006-\square$

12. Which diversification strategy (value added processes) your cooperative adopts when seeking after new international markets?

(choose as many alternatives as necessary)

$\square$ The cooperative does not trade value added products internationally (it is limited to international trade of commodities)

$\square$ The cooperative is developing studies to introduce industrialization process (value added) aimed at external markets

$\square$ The cooperative develops customized products for international customers from their existing product mix

$\square$ The cooperative introduces new business matrixes to serve international market niches or demand

$\square$ Other 
13. From a marketing standpoint, how does your cooperative negotiates value added products in the international market?

(register the percentage of each alternative in relation to the total)

$\%$ - Products leave the cooperative with the customer or distributor label
$\%$ - Products leave with the cooperative label until the distribution network
$\%$ - Products leave with the cooperative label until the final customer
$\%$ - Other

$100 \%$ - TOTAL

14. Is your cooperative already involved or looking for business partnerships (strategic alliances, joint ventures, etc.) regarding agro-industrialization process in order to meet the external market demand?

(choose as many alternatives as necessary)

$\square$ Yes, diversification is becoming feasible through alliances with Brazilian or international capital companies

$\square$ Yes, diversification is becoming feasible through alliances with Brazilian or international cooperatives

$\square$ Yes, but it is not easy to find partners with the same interests as ours

$\square$ No, we prefer to operate without partners

$\square$ Other

15. What are the main objectives expected with the adoption of business partnerships (strategic alliances, joint ventures, etc.) in order of importance?

(rank in order of importance where " 1 " is the most important, "2" is the second most important, and so on, without repeating numbers)

Access to distribution channels abroad

Access to new technologies

Access to complementary stages of industrialization processes in order to reduce the need of investment in industrial plants (refrigerating chambers, slaughterhouses, etc.)

Other 
16. What factors encourage your cooperative to seek after new diversification strategies (value added process) in order of importance?

(rank in order of importance where " 1 " is the most important, " 2 " is the second most important, and so on, without repeating numbers)

\begin{tabular}{|c|}
\hline Reduce the non-viability risk of the agriculture business \\
\hline Obtain better commercialization prices \\
\hline Create revenue alternatives to members - Increase members' income \\
\hline Absorb the technical and productive capacity of the cooperative \\
\hline Feasibility of adopting differentiated strategies in the external market \\
\hline International market demand for differentiated products \\
\hline Other \\
\hline
\end{tabular}

17. Indicate the relevance of each factor considering it as an ENCOURAGEMENT to your cooperative international operations.

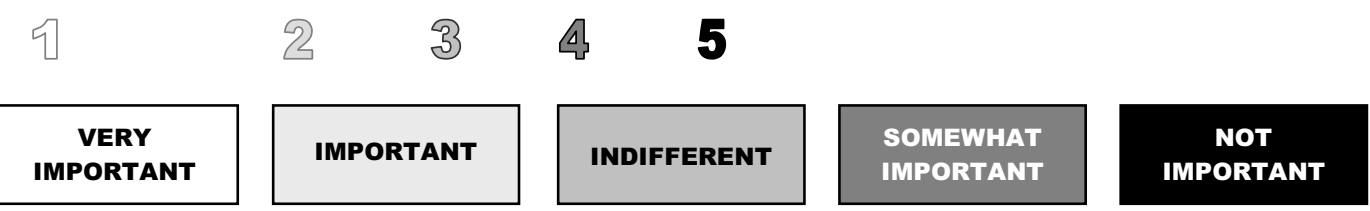

\section{ๆ2 345}

$\bigcirc \bigcirc \bigcirc \bigcirc$ Stagnant or saturated home market (surplus production)

$\bigcirc \bigcirc \bigcirc \bigcirc$ Better commercialization prices

$\bigcirc \bigcirc \bigcirc \bigcirc$ Possibility of increasing cooperative's and member's income and profitability

$\bigcirc \bigcirc \bigcirc \bigcirc$ Reduce business risk

$\bigcirc \bigcirc \bigcirc \bigcirc$ Commercial leverage to reverse under-used production capacity

$\bigcirc \bigcirc \bigcirc \bigcirc$ Acquire core competences for innovation and diversification of products

$\bigcirc \bigcirc \bigcirc \bigcirc$ Access to new sources of information overseas

$\bigcirc \bigcirc \bigcirc \bigcirc$ Benefit from fiscal and tax incentives (local and international)

$\bigcirc \bigcirc \bigcirc \bigcirc$ Ensure the survival of the business

$\bigcirc \bigcirc \bigcirc \bigcirc$ Access to distribution channels abroad

$\bigcirc \bigcirc \bigcirc \bigcirc$ Existence of potential partners in the country of destination

$\bigcirc \bigcirc \bigcirc \bigcirc$ Access to specialized resources abroad (capital, labor, etc.)

$\bigcirc \bigcirc \bigcirc \bigcirc$ Exploit market niches

$\bigcirc \bigcirc \bigcirc \bigcirc$ Access to financial operations (Advances on exchange contracts, etc)

$\bigcirc \bigcirc \bigcirc$ Inter-cooperation (cooperation among cooperatives, national and international)

$\bigcirc \bigcirc \bigcirc \bigcirc \bigcirc$ Other 
18. Indicate the relevance of each factor considering it as a FACILITATOR to your cooperative international operations.

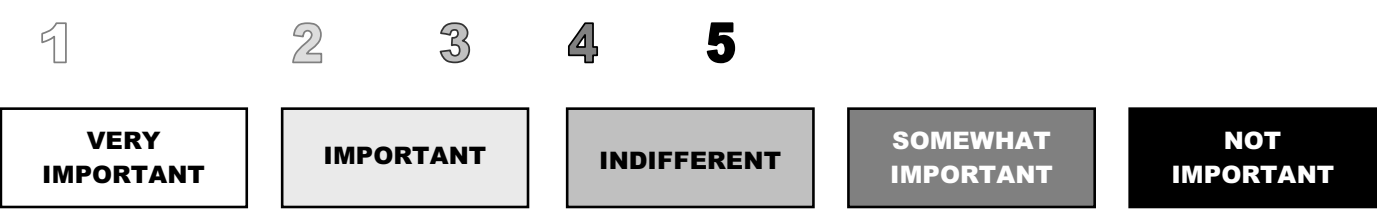

\section{ๆ2 345}

$\bigcirc \bigcirc \bigcirc \bigcirc$ Geographical proximity with the country of destination

$\bigcirc \bigcirc \bigcirc \bigcirc$ Proximity to the culture and language of the destination country

$\bigcirc \bigcirc \bigcirc \bigcirc$ Mix of value added products of the cooperative

$\bigcirc \bigcirc \bigcirc \bigcirc$ Network of contacts with public and private institutions in the country of destination

$\bigcirc \bigcirc \bigcirc \bigcirc$ Relations with Brazilian exporting entities (APEX, ABIPEX, etc.)

$\mathrm{\bigcirc} \bigcirc \bigcirc \bigcirc$ Be a cooperative

$\bigcirc \bigcirc \bigcirc \bigcirc$ Existence of potential partners in the country of destination

$\bigcirc \bigcirc \bigcirc \bigcirc$ Possess certifications that meet requirements for food safety (certification of quality, environmental management, traceability, etc.).

$\bigcirc \bigcirc \bigcirc \bigcirc$ Possess technological production parity with developed markets

$\bigcirc \bigcirc \bigcirc \bigcirc$ Access to distribution channels abroad

$\bigcirc \bigcirc \bigcirc \bigcirc$ Access to specialized resources abroad (capital, labor, etc.)

$\bigcirc \bigcirc \bigcirc \bigcirc$ Access to new sources of information overseas

$\bigcirc \bigcirc \bigcirc \bigcirc$ Existence of trade agreements or participation in economic blocks

$\bigcirc \bigcirc \bigcirc \bigcirc$ Inter-cooperation (cooperation among cooperatives, national and international)

$\bigcirc \bigcirc \bigcirc \bigcirc \bigcirc$ Other 
19. Indicate the relevance of each factor considering it as a HINDRANCE to your cooperative international operations.

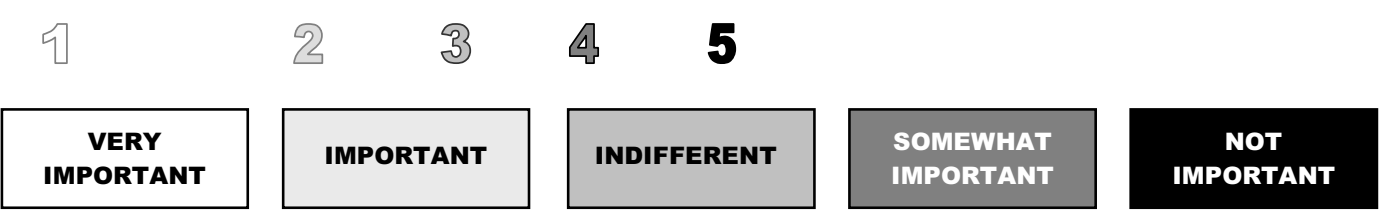

\section{ๆ23 45}

$\bigcirc \bigcirc \bigcirc \bigcirc \bigcirc \quad$ Brazilian exchange rate policy

$\bigcirc \bigcirc \bigcirc \bigcirc \bigcirc \quad$ Tax and fiscal barriers

$\bigcirc \bigcirc \bigcirc \bigcirc \quad$ Non-fiscal or tax barriers (technical, sanitary, environmental, etc.)

$\bigcirc \bigcirc \bigcirc$ Bureaucracy and legal issues regarding the process of internationalization

$\bigcirc \bigcirc \bigcirc \bigcirc \bigcirc \quad$ Brazil cost

$\bigcirc \bigcirc \bigcirc \bigcirc \quad$ Lack of trade agreements and participation in economic blocks

$\bigcirc \bigcirc \bigcirc \bigcirc \quad$ Lack of technological skills of the workforce in Brazil

$\bigcirc \bigcirc \quad$ Marketing strategies costs for accessing the international market (brand exposure, access to channels, participation in fairs, etc.).

$\bigcirc \bigcirc$ Product adaptation costs to international requirements (formulation, packaging, technology, certification of origin, quality, etc.)

$\bigcirc \bigcirc \bigcirc \bigcirc \quad$ Be a cooperative

$\bigcirc \bigcirc \bigcirc \bigcirc \quad$ Complexity in managing international operations

$\bigcirc \bigcirc \bigcirc \bigcirc \quad$ Lack of production regularity

$\bigcirc \bigcirc \bigcirc \bigcirc \quad$ Lack of storage, transportation and distribution infrastructure

$\bigcirc \bigcirc \bigcirc \quad$ Structure adequacy to meet international trade requirements

$\bigcirc \bigcirc \bigcirc \bigcirc \bigcirc \quad$ Investment risk

$\bigcirc \bigcirc \bigcirc$ System and distribution channels of the destination country

$\bigcirc \bigcirc \bigcirc \bigcirc \quad$ Culture and language of the destination country

$\bigcirc \bigcirc \bigcirc \bigcirc \bigcirc$ Brazil's image abroad

$\bigcirc \bigcirc \bigcirc \bigcirc \bigcirc$ Other 
20. Indicate the level of agreement with the statements below regarding the RESULTS achieved in the internationalization process of your cooperative.

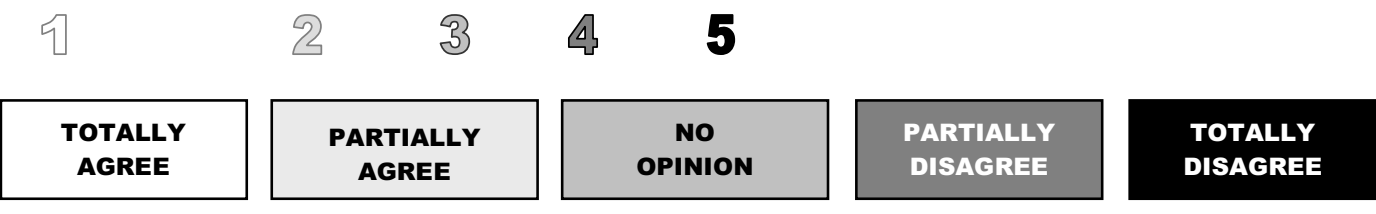

\section{ๆ2345}

$\bigcirc \bigcirc \bigcirc \bigcirc$ The cooperative became more competitive, improving its performance and productivity (locally and internationally)

$\bigcirc \bigcirc \bigcirc$ Modified the mix of products of the cooperative

$\bigcirc \bigcirc \bigcirc$ Provided new alternatives to the cooperative activities (increase of flexibility, changes in its structure, etc.).

$\bigcirc \bigcirc \bigcirc \bigcirc$ Increased the brand exposure

$\bigcirc \bigcirc \bigcirc \bigcirc$ Consolidated relationships with customers / distributors abroad

$\bigcirc \bigcirc \bigcirc \bigcirc$ Allowed to pay better prices to members/producers

$\bigcirc \bigcirc \bigcirc$ Provided greater stability in the activity of the producer

$\bigcirc \bigcirc \bigcirc \bigcirc$ Increased the social result of the cooperative

$\bigcirc \bigcirc \bigcirc \bigcirc$ Increased the profitability of the cooperative

$\bigcirc \bigcirc \bigcirc \bigcirc$ Members resist to operate internationally

$\bigcirc \bigcirc \bigcirc \bigcirc$ It was not a good experience - the international operations of value added products were suspended

$\bigcirc \bigcirc \bigcirc \bigcirc$ It was not a good experience, however new international alternatives are being sought

$\bigcirc \bigcirc \bigcirc \bigcirc$ Even operating at a loss in some periods, internationalization has become an important activity for the cooperative

$\bigcirc \bigcirc \bigcirc \bigcirc$ Facilitated the fulfillment of the economic objectives of the cooperative

$\bigcirc \bigcirc \bigcirc \bigcirc$ Facilitated the fulfillment of the social objectives of the cooperative

$\bigcirc \bigcirc \bigcirc \bigcirc \bigcirc \quad$ Other

The disclosure of the name of the cooperative is authorized only if bound to this research.

YES $\square$ NO 